\title{
Users' Perceptions of the WhatsApp Usefulness in Learning
}

\author{
Lestari Widodo ${ }^{1}$ \\ State University of Malang, East Java, INDONESIA
}

Received 30 March 2019 • Revised 13 June 2019 • Accepted 10 July 2019

\begin{abstract}
The purpose of this study was to know users' perception towards WhatsApp in several aspects such useful, ease of use, ease of learning and satisfaction. Descriptive method and questionnaire developed by Lund, A. M (2001) were used in this study. This questionnaire was consisted of 30 questions and translated to Indonesian. The subjects of this study were 175 participants who were of different age and professions. The result of this study shows that the participants give positive response for every aspect. The mean response of participants' perception argued that WhatsApp is useful, ease to use, ease to learning and give satisfaction. Therefore, WhatsApp can implement in learning system.
\end{abstract}

Keywords: WhatsApp, user'perception, learning.

\section{Introduction}

Technology expansion in the $21^{\text {st }}$ century was very fast. The technology can help people' job rapidly and easily. An example is the use of software or application. Public facilities and professionals have mobile device connected with Internet in a range of fields (Giordano, 2014). The development of new application was to facility communication among users with improve taking, strong and transmission pictures (Al-Hadithy, 2012). There is new trend in the Information Communication Technology (ICT) in the world called social networking. Many definitions and views about social networking refer to tools that facilitate people to meet, interact and discuss ideas (Anderson, 2010). One of them is WhatsApp.

Whatsapp sends message in real time and is as one of the most popular application of communication in the 21th century (Ahad \& Lim, 2014). WhatsApp facilitate in texting or communicate real time, include to share easy information (e.g. contact list) or media content (e.g. audio, video file, pictures, and located data). The last years, there were many literatures investigated the use of WhatsApp (Church \& Oliveria, 2013; Soliman \& Salem, 2014; O'Hara et al., 2014; Devi \& Tevera, 2014). WhatsApp was the most extensive mobile application for people to

${ }^{1} \mathrm{PhD}$ student.

(C) Authors. Terms and conditions of Creative Commons Attribution 4.0 International (CC BY 4.0) apply. Correspondence: Lestari Widodo, State University of Malang, East Java, INDONESIA. E-mail: widodo.1603218@students.um.ac.id. 
send message such share text and content (e.g., audio, video, picture, location and data) (Karpisek, 2015).

The studied by Ahad (2014) showed that WhatsApp used students in discussion term and share information related to material of study, part of their daily life communication with family, friends and relative. Moreover, students improved critics' issue of used WhatsApp frequency which included necessary to attend WhatsApp message immediately, sometimes unappropriate information or contents of media, mobile connection and habit such as addict (e.g distrub in their study).

In Indonesia, forty percent of population are using WhatsApp (https://www.statista.com/statistics/291540/mobile-internet-user-whatsapp/). It showed that the most of people know and use WhatsApp. Therefore, it needs to know the response of users towards WhatsApp on the some of aspects such as useful, ease of use, and ease of learning. It can become basic to implement WhatsApp on various area such learning.

\section{Method}

This study was descriptive research to know users' perception of WhatsApp. This study was used quantitative research design. The data were collected by using questionnaire developed by Lund (2001). The redaction of questionnaire was appropriate application which was studied and was translated to Indonesian. The questionnaire questions consisted of 5 parts such the identity of respondent, useful aspect, ease of use aspect, ease of learning aspect, and satisfaction aspect. Each aspect has a few different questions. The scale was used in this questionnaire was likert scale that has modification become 4 scales (Hadi, 1991). The data were collected through online form. The technology expansion rapidly makes online survey to become more effective. The subject of this study were 176 participants. The data analyzed by calculation percent of each aspect. The interpretation of analyze become conclusion.

\section{Finding}

\subsection{Demographics}

The participants of this study were consisted of $54.29 \%$ male and $45.71 \%$ female. The participants have experience to use WhatsApp application. There are many kind of their age who $16^{\text {th }}$ to $35^{\text {th }}$ years. The data are shown in Figure 1.

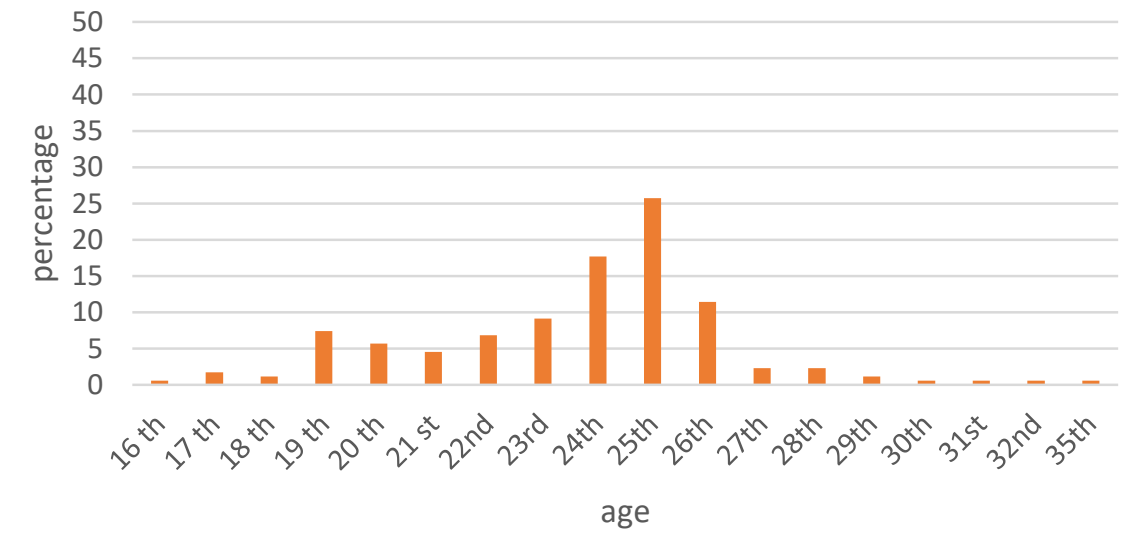

Figure 1. Percentage of participants 
Figure 1 shows that the most of number participants are in $25^{\text {th }}$ years old. In another word, the domination of participants were they who have age 19 th to $26^{\text {th }}$ years old. Moreover, the participants have many kinds of professions. The occupation of participants are shown in Table 1. The participants come from many places in Indonesia.

Table 1. The participants' professions

\begin{tabular}{ll}
\hline Profession & Percentage \\
\hline $\begin{array}{l}\text { Students in } \\
\text { University }\end{array}$ & $67,43 \%$ \\
\hline Health & $1,71 \%$ \\
\hline Enterpreneur & $15,43 \%$ \\
\hline Researcher & $1,14 \%$ \\
\hline Students & $2,86 \%$ \\
\hline Teacher & $7,43 \%$ \\
\hline Lecturer & $1,71 \%$ \\
\hline $\begin{array}{l}\text { Government } \\
\text { employees }\end{array}$ & $1,71 \%$ \\
\hline Artist & $0,57 \%$ \\
\hline
\end{tabular}

The participants come from 5 islands in Indonesia such Sumatera, Java, Bali, Kalimantan, and Sulawesi. The percentage of participants were from Sumatera, such Jambi (17.14\%), Lampung (1.71\%), South Sumatera (1.14), North Sumatera (2.28 \%) and West Sumatera (0.57\%). Percentage of participants were from Java Island, such East Java (26.28 \%), Yogyakarta (21.71\%), Banten (0.57), Jakarta (4.57\%), Central Java (13.14\%), and West Java (6.85\%). The participants come from others islands such East Kalimantan (0.57\%), South East Sulawesi (0.57\%), South Sulawesi (0.57\%), Bali (1.14\%) and the students from Indonesia in abroad (1.14\%)

\subsection{Useful}

Table 2. Users' perception towards Whatsapp on useful aspect

\begin{tabular}{lllll}
\hline \multicolumn{1}{c}{ Aspects } & SD & $\begin{array}{l}\text { D } \\
\text { (\%) }\end{array}$ & $\begin{array}{l}\text { A } \\
\text { (\%) }\end{array}$ & $\begin{array}{l}\text { SA) } \\
\text { (\%) }\end{array}$ \\
\hline WhatsApp helps me be more effective & 0 & 2.8 & 39 & 58.2 \\
\hline WhatsApp helps me be more productive & 0 & 7.9 & 66.1 & 26 \\
\hline WhatsApp is useful & 0 & 0 & 42.9 & 57.1 \\
\hline $\begin{array}{l}\text { WhatsApp gives me more control over the activities in my } \\
\text { life }\end{array}$ & 0.6 & 28.2 & 58.2 & 13 \\
\hline $\begin{array}{l}\text { WhatsApp makes the things I want to accomplish easier to } \\
\text { get done }\end{array}$ & 0 & 13.6 & 68.4 & 18.1 \\
\hline $\begin{array}{l}\text { WhatsApp saves me time when I use it } \\
\text { WhatsApp meets my needs }\end{array}$ & 0.6 & 16.4 & 66.1 & 16.9 \\
\hline WhatsApp does everything I would expect it to do & 0 & 3.4 & 72.9 & 23.7 \\
\hline
\end{tabular}

Note: Strongly Disagree (SD), Disagree (D), Agree (A), Strongly Agree (SA)

Based on Table 2, the users of WhatsApp give positive response such as WhatsApp helps users be more effective. The introduction of sophisticated communication service through internet has changed the interaction way among users. It makes user can change text message 
such file, audio, video and pictures (Anglano, 2014). The result supported by Norfaezah (2015) shows that WhatsApp can help students to share many things with lecturer. The contents of WhatsApp makes users more productive. It showed by users' percentage $66.1 \%$ "agree" and $26 \%$ "very agree".

The users of WhatsApp give positive response because it can make users more productive. The instant message of WhatsApp can become potential for everyone such as a bridge to share information between teacher and students. The quickly change and develop in ICT influences all aspects in the life (Fattah, 2015). One of them is in education area. This application can help student to share study materials.

The participants feel that WhatsApp is easy to use so they gave the positive response. As social media has a wide prospect in society which is above almost one from four persons in world used social media (Burke et al., 2010). WhatsApp is agreed people' necessary. In another context, WhatsApp was used as the aware technology that was supported pleasure for family member who lives separated (Brown et al., 2007). Technology was a vital thing in the world now and created easy for everything (Bansal \& Joshi, 2014).

WhatsApp makes the things I want to accomplish easier to get done. This result supported by the result of previous study. Community Communication Forum (FKM) and users' ICT in form of WhatsApp group were an effective communication way for two directions (Dialogical Communication) between a company and heir so Independent Waste Bank CSR Program can be accepted and implemented in complicity participant way with people especially in Kebon Manis Northern Cilacap district (Nurjanah, 2017).

\subsection{Ease of use}

Table 3. Users' perception towards WhatsApp on ease of use aspect

\begin{tabular}{|c|c|c|c|c|}
\hline Aspect & $\begin{array}{l}\text { SD } \\
\text { (\%) }\end{array}$ & $\begin{array}{c}\text { D } \\
\text { (\%) }\end{array}$ & $\begin{array}{c}A \\
(\%)\end{array}$ & $\begin{array}{l}\text { SA } \\
\text { (\%) }\end{array}$ \\
\hline WhatsApp is easy to use & 0 & 0 & 45.2 & 54.8 \\
\hline WhatsApp is simple to use & o & o & 48 & 52 \\
\hline WhatsApp is user friendly & $\mathrm{O}$ & $\mathrm{O}$ & 66.7 & 32.8 \\
\hline $\begin{array}{l}\text { WhatsApp requires the fewest steps possible to } \\
\text { accomplish what I want to do with it }\end{array}$ & $\mathrm{o}$ & 19.8 & 66.1 & 14.1 \\
\hline WhatsApp is flexible & $\mathrm{O}$ & 4 & 72.9 & 23.2 \\
\hline Using Whatsapp is effortless & 0 & 0.5 & 60.5 & 39 \\
\hline User can use it without written instructions & $\mathrm{O}$ & 13.6 & 58.8 & 27.7 \\
\hline User don't notice any inconsistencies as I use it & $\mathrm{O}$ & 16.9 & 66,3 & 16.9 \\
\hline Both occasional and regular users would like it & o & 3.4 & 67.2 & 29.4 \\
\hline User can recover from mistakes quickly and easily & 0 & 27.7 & 62.7 & 9.6 \\
\hline User can use it successfully every time & $\mathrm{O}$ & 11.3 & 67.8 & 20.3 \\
\hline
\end{tabular}

The Table 3 showed users' perception toward the ease to use WhatsApp. Nowdays, the jobs used whatshapp and other application to send instant message were found such service to more close way and private to communicate with friends, better basic needs in association (Karapanos, Teixeira \& Gouveia, 2015).

WhatsApp is easy to learning because the procedure in WhatsApp is easy. WhatsApp needs steps which is to get what user want in WhatsApp. It means that there is not difficult. The result supported by Mistar and Embi (2016) shows that the students' attitude towards WhatsApp were in high level. It is because WhatsApp is ease to use, to learn, to share knowledge quickly and to give information easily in discussion. 


\subsection{Ease of learning}

Table 4. Users' perception towards WhatsApp on ease of learning aspect

\begin{tabular}{|c|c|c|c|c|}
\hline Aspect & $\begin{array}{l}\text { SD } \\
\text { (\%) }\end{array}$ & $\begin{array}{c}D \\
(\%)\end{array}$ & $\begin{array}{c}A \\
(\%)\end{array}$ & $\begin{array}{l}\text { SA } \\
\text { (\%) }\end{array}$ \\
\hline User learned to use it quickly & 0 & 4 & 65 & 31.1 \\
\hline User easily remember how to use it & $\mathrm{O}$ & 1.1 & 59.3 & 39.5 \\
\hline WhatsApp is easy to learn to use it & o & 2.8 & 56.5 & 40.7 \\
\hline User quickly became skillful with it & O & 5.6 & 61.6 & 32.8 \\
\hline
\end{tabular}

Based on Table 4, participants give positive response because WhatsApp is easy to learn. It shows on percentage in "agree" and "strongly agree".

\section{Satisfaction}

Table 5. Users' perception towards WhatsApp on satisfaction aspect

\begin{tabular}{|c|c|c|c|c|}
\hline Aspect & $\begin{array}{l}\text { SD } \\
\text { (\%) }\end{array}$ & $\begin{array}{c}\text { D } \\
\text { (\%) }\end{array}$ & $\begin{array}{c}A \\
(\%)\end{array}$ & $\begin{array}{l}\text { SA } \\
\text { (\%) }\end{array}$ \\
\hline User satisfied with WhatsApp & o & 0.6 & 67.2 & 32.2 \\
\hline User would recommend it to a friend & O & 1.1 & 67.8 & 31.1 \\
\hline WhatsApp is fun to use & $\mathrm{O}$ & 2.3 & 29.4 & 68.4 \\
\hline WhatsApp works the way I want it to work & $\mathrm{O}$ & 8.5 & 70.6 & 20.9 \\
\hline WhatsApp is wonderful & O & 12.4 & 65 & 22.6 \\
\hline User feel I need to have whatsApp & $\mathrm{O}$ & 0 & 60.5 & 39.5 \\
\hline WhatsApp is pleasant to use & $\mathrm{O}$ & 1.1 & 68.4 & 30.5 \\
\hline
\end{tabular}

\section{Discussion}

The importance of mobile learning was improved since the beginning of $21^{\text {th }}$ century (Fattah, 2015). Application that can use in mobile learning was WhatsApp. WhatsApp is smartphone application for sending instant message (Mistar \& Embi, 2016). In this study, participants gave positive perception towards useful, ease of use, ease of learning and satisfaction aspect.

WhatsApp has potential to use in learning. The researcher often was found their students that ask with them: "Are you use WhatsApp?" or "Are you use chat?" Mobile device provide significant chance to help students become more independently and has potential to change process of transfer of learning and teaching in high education (Bansal \& Joshl, 2014). Another study shows the relationship between parent and teacher through WhatsApp. Use of WhatsApp enables communication between parent and teacher, and to build relationship one another as participation in education system (Mayangsari \& Aprianti, 2017).

The most of discussion in group was almost in middle of night. Students were supported a fact that M-learning is flexible to access the kind of resource to study wherever and exactly when (Jaradat, 2014). Turkle (2012) argued that we prefer technology to create our feel related to ways that we can control. WhatsApp prefers to use to connect between social and people who they want, it is like that people use same social application (Mongeau \& Hennningsen, 2015). 


\section{Conclusion}

WhatsApp is useful for each user. WhatsApp has contents to change text, file, audio, video, and picture. Moreover, WhatsApp is ease to use and to learn. Based on useful and ease aspect, WhatsApp gives satisfaction for users, so WhatsApp can be implemented in and outside of classroom. The shipping of WhatsApp instant message has potential to bridge and share information between educator and students (Rambe \& Chipunza, 2013).

\section{Acknowledgements}

This research did not receive any specific grant from funding agencies in the public commercial, or not-for-profit sectors.

The author declares no competing interests.

\section{References}

Adhianty, Nu. (2017). Community Communication Forum (FKM) \& WhatsApp (WA) Group: Dialogic Communication between Company-Community in Achieving Community Development in Indonesia. Pros. ICoSaPS, Conference Proceedings of The 3rd International Conference on Social and Political Science "The Impact of Information Technology on Social and Political Dynamics" (2016), Volume 2017 (pp. 334-343). KnE Social Science.

Ahad, A. D., \& Lim, Syamimi, M. A. (2014). Convenience or Nuisance?: The 'WhatsApp' Dilemma. Proc. The International Conference on Communication and Media 2014. Elsevier 189-196 Malaysia.

Al-Hadithy, N., Gikas, P. D., \& Al-Nammari, S. S. (2012). Smartphones in orthopaedics. Int. Orthop. 36(8), $1543-1547$.

Bansal, T., \& Joshi, D. (2014). A study of students' experiences of mobile learning. Global Journal of Human-Social Science: H Interdiciplinary, 14(4), 26-33.

Brown, B., Taylor, A. S., Izadi, S., Sellen, A., Jofish'Kaye, J., \& Eardley, R. (2007). Locating family values: A field trial of the Whereabouts clock (pp. 354-371). Berlin Heidelberg: Springer.

Burke, M., Marlow, C., \& Lento, T. (2010). Social network activity and social wellbeing. In Proceedings of the SIGCHI Conference on human factors in computing systems (1909-1912). ACM.

Church, K., \& Oliveira, R. D. (2013). What's up with WhatsApp? Comparing mobile instant messaging behaviors with traditional SMS. MOBILE HCI 2013-Collaboration and Communication, August 30, 2013 (pp. 352-361). Munich, Germany.

Cosimo, A. (2014). Forensic analysis of WhatsApp Messenger on Android Smartphones. Elsevier, 11(3), 201213. http://dx.doi.org/10.1016/j.diin.2014.04.003

Devi, T. S., \& Tevera, S. (2014). Use of social networking site in the University of Swaziland by the health science students: A Case study. Journal of Information Management, 1(1), 19-26.

Fattah, Said Fathy El Said Abdul (2015). The effectiveness of using WhatsApp Messenger as one of mobile learning techniques to develop students' writing skills. Journal of Education and Practice, 6(23), 115-127.

Franko, O. I. (2011). Smartphone apps for orthopaedic surgeons. Clin. Orthop. Relat. 469(7), 2042-2048.

Giordano, V., Koch, H. A., Mendes, C. H., Bergamin, A., de Souza, F. S., \& do Amaral, N. P. (2014). WhatsApp messenger is useful and reproducible in the assessment of tibial plateau fractures: Inter-and intra-observer agreement study. Elsevier. 
Goost, H., Witten, J., Heck, A., Hadizadeh, D. R., Weber, O. et al. (2012). Image and diagnosis quality of Xray image transmission via cell phone camera: a project study evaluating quality and reliability, PLOS ONE, 7(10), 1-6.

Jardat, R. M. (2014). Students' attitudes and perceptions towards using m-learning for French language learning: A case study on Princess Nora University. International Journal of Learning Management Systems, 2(1), 33-44.

Karapanos, E., Teixeira, P., \& Gouveia, R. (2016). Need fulfillment and experiences on social media: A case on Facebook and WhatsApp. Elsevier, 55(2016), 888-897.

Karpisek, F., Baggili, I., \& Breitinger, F. (2015). WhatsApp network forensics: Decrypting and understanding the WhatsApp call signaling messages. Elsevier. Volume 15, 110-118 http://dx.doi.org/10.1016/j.diin.2015.09.002

Lund, A.M. (2001) Measuring usability with the USE Questionnaire. STC Usability SIG Newsletter, 8: 2.

Mayangsari, I. D., \& Aprianti, A. (2017). Understanding communication among parents and teachers in WhatsApp. Case study in Bandung, Indonesia. Malaysian Journal of Social Science and Humanities, 2(2) 19-24.

Mistar, I. B., \& Embi, M. A. (2016). Students' perception on the use of WhatsApp as a learning tool in ESL Classroom. Journal of Education and Social Sciences, 4 (June), 96-104.

Mongeau, P. A. \& Henningsen, M. L. M. (2015). Engaging theories in interpersonal communication: Multiple perspectives. Sage Publication. USA.

Norfaezah, M. H. (2015). Penggunaan Aplikasi 'WhatsApp' Dalam Pembelajaran \& Pengajaran (P\&P) di KUIS. 1st Global Conference on Technology in Language Learning 20015 (GLIT2O15).

O'Hara, K., Massimi, M., Harper, R., Rubens, S., \& Morris, J. (2014). Everyday dwelling with WhatsApp. Proceedings of the 17th ACM conference on Computer supported cooperative work \& social computing (pp. 1131-1142). ACM, Baltimore, MD, USA.

Rambe, P. \& Chipunza, C. (2013). Using Mobile devices to leverage student access to collaborativelygenerated resources: A case of WhatsApp instant messaging at a South African University. Pros. International Conference on Advanced Information and Communication Technology for Education (ICAICTE 2013). Atlantis Press.

Soliman, D. A., \& Salem, M. S. (2014). Investigating intention to use mobile instant messenger: The influence of socialibility, selfexpressiveness, and enjoyment. The Journal of American Academy of Business, Cambridge, 19(2), 286-293.

Turkle, S. (2012). Alone together: Why we expect more from technology and less from each other. Basic Books.

https://www.statista.com/statistics/291540/mobile-internet-user-whatsapp/ 
L. Widodo - Users' Perceptions of the WhatsApp Usefulness in Learning

C O A $\mathrm{s}$ 